\title{
A Rare Cause of Pelvic Pain: Degenerated Myoma Within a Rudimentary Horn of Unicornuate Uterus
}

\author{
Nadir Bir Pelvik Ağrı Nedeni: Uterus Rudimenter Hornu Iç̧erisinde Dejenere Miyom
}

\author{
Alaaddin Nayman', Ulku Kerimoglu², Mehmet Colakoglu³ \\ 'Department of Radiology, Vezirkoprü State Hospital, Samsun, Turkey \\ 2Department of Radiology, Meram Medicine Faculty, Konya, Turkey \\ ${ }^{3}$ Department of Obstetrics And Gynecology, Meram Medicine Faculty, Konya, Turkey
}

\section{ABSTRACT}

Introduction: Treatment options for the different congenital uterine abnormalities of the uterus vary considerably; therefore, preoperative imaging plays a crucial role in the management.

Case Report: A 29-year-old woman who had pelvic pain and vomiting, were examined with pelvic ultrasound (US) and magnetic resonance imaging (MRI). A hypoechoic pelvic mass was detected via ultrasound. A degenerated myoma was estimated, but to exclude a mass from the right ovary, a pelvic MRI was performed. The degenerated myoma was considered and was located in the rudimentary horn of the right side of the uterus. This appearance was confirmed by laparotomy.

Conclusion: Although ultrasound is the first imaging modality for acute pelvic pathologies, magnetic resonance imaging is superior to ultrasound in evaluating the congenital abnormalities of the uterus.

Keywords: US, MRI, uterine anomaly, degenerated myoma

Received: 10.07.2012 Accepted:07.05.2013

\section{ÖZET}

Giriş: Farklı konjenital uterin anomalilerde tedavi seçenekleri önemli ölçüde değişebilmektedir, bu nedenle operasyon öncesi görüntüleme kritik önem arzetmektedir.

Olgu Sunumu: Pelvik ağrı ve kusma şikayetleri olan 29 yaşında bayan hasta USG ve pelvik MRG ile değerlendirildi. USG'de pelvik bölgede dejenere miyomu düşündüren hipoekoik kitle saptandı. Bunun üzerine over kitlesi ekartasyonu için pelvik MRG yapıldı ve MRG'de dejenere miyom görüldü. Miyom uterus sağ tarafında rudimenter horn içerisinde idi. Görünüm laparatomi ile doğrulandı.

Sonuç: Akut pelvik patolojilerde USG ilk tercih olmakla birlikte konjenital anomalierin tanısında MRG daha üstündür.

Anahtar Kelimeler: USG, MRG, uterin anomali, dejenere miyom Geliş Tarihi: 10.07.2012 Kabul Tarihi: 07.05.2013

\section{Introduction}

Congenital abnormalities of the uterus are estimated to affect $0.1 \%-0.5 \%$ of women of reproductive age (1). There are a variety of different anomalies, but they represent a spectrum of disorders rather than discrete entities, and it may not be possible to group all abnormalities into one particular class. Although uterine malformations may be entirely asymptomatic, approximately $25 \%$ of patients with an anomaly have sub-fertility, and up to 9\% of women are infertile or suffer from recurrent miscarriages (2). Treatment options for the different forms of abnormality vary considerably; therefore, preoperative imaging plays a crucial role in the management (3).

\section{Case Report}

A 29-year-old woman visited our hospital with pelvic pain and vomiting. A pelvic ultrasonographic examination obtained after filling of the bladder revealed a hypoechoic pelvic mass with a necrotic center measuring $6 \times 5.5 \mathrm{~cm}$ (Figure 1). The left ovary 
was normal, and the right ovary was adjacent to the mass (Figure $2 \mathrm{a}$ and $\mathrm{b}$ ). Because the patient was a virgin, transvaginal ultrasound could not be performed. A degenerated myoma was considered, but to exclude a mass from the right ovary, a pelvic MRI was recommended. MR imaging was performed in a 1.5 T scanner (Siemens, Symphony, Erlangen, Germany), including sagittal and transverse T2-weighted and T1-weighted images obtained before and after administration of intravenous contrast material.

Magnetic resonance imaging revealed a mass that demonstrated heterogeneous and mostly hypointense signal intensities on both T1- and T2-weighted images. After administration of intravenous contrast material, the mass heterogeneously enhanced. A myoma was considered and was located in the rudimentary horn of the right side of the uterus. The left horn was normal in configuration (Figure 3). Subsequently, a laparotomy was performed, revealing a degenerated myoma in the obstructed right rudimentary horn of a unicornuate uterus (Figure 4).

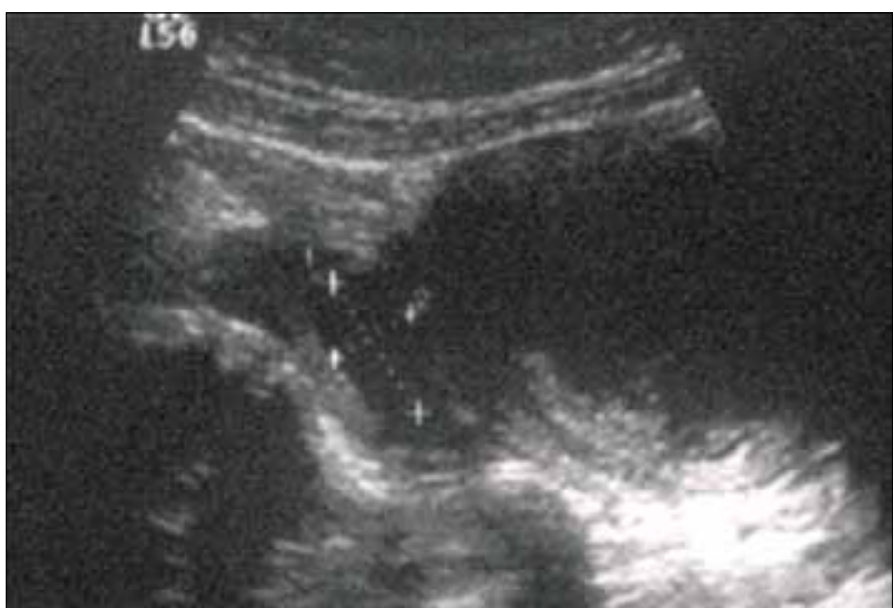

Figure 1. Transverse sonogram of pelvis shows the right ovary was adjacent to the mass

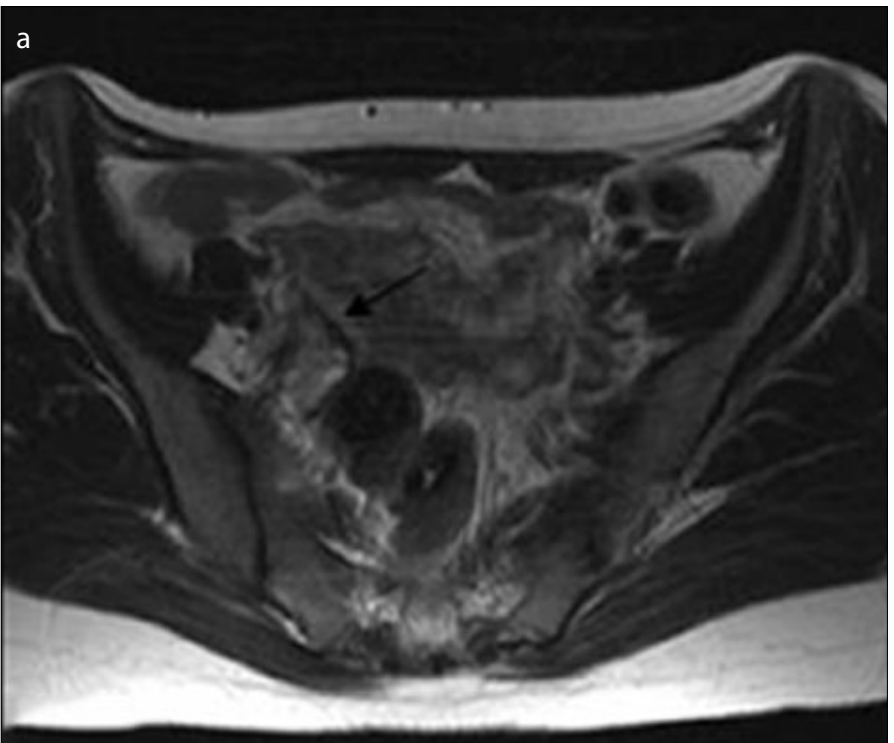

\section{Discussion}

Uterine anomalies are uncommon in the general population but occur in approximately 1\%-6 \% of the female population. The incidence is much higher in women undergoing evaluation for primary infertility (4). Failure of fusion, migration, or development of the paired Mullerian structures leads to uterine anomalies. According to the American Fertility Society Classification, they are divided into seven categories depending on the stage of organogenesis in which these failures arise (5). Unilateral complete or partial failure of Mullerian duct development results in a unicornuate uterus. This is the least common form of uterine anomaly, accounting for 1\%-2\% of all cases (6). A unicornuate uterus may be isolated, manifesting in $35 \%$ of patients, although it is usually associated with variable degrees of a rudimentary uterine horn. A noncavitary rudimentary horn without associated endometrium is seen in 33\% of cases, and that with an endometrial segment is seen in 32\%. A cavitary rudimentary horn is designated "communicating" if there is communication with the endometrium of the contralateral horn (10\% of cases) and "noncommunicating" if there is no such communication (22\% of cases) (7). Transabdominal US has been of limited use in the identification and differentiation of Mullerian duct anomalies. Endovaginal sonography offers several advantages over transabdominal US. There is improved visualization of the uterine anatomy through placement of the transducer in the vaginal vault and avoidance of subcutaneous fat. The use of high-frequency probes also allows increased resolution of pelvic structures compared with that of scans obtained through a fluid-filled bladder. Unfortunately, because the patient was Muslim, transvaginal ultrasound could not be performed secondary to religious belief. Given the ability to allow a distinction of internal and external uterine anatomy, MR imaging appears well suited for the diagnosis of Mullerian duct anomaly subtypes (8). To the best of our knowledge, our case is the first case presenting with a myoma in a unicornuate uterus. Although ultrasound is the first diagnostic imaging for pelvic pathologies, there is an exception, and magnetic resonance imaging is superior to ultra-

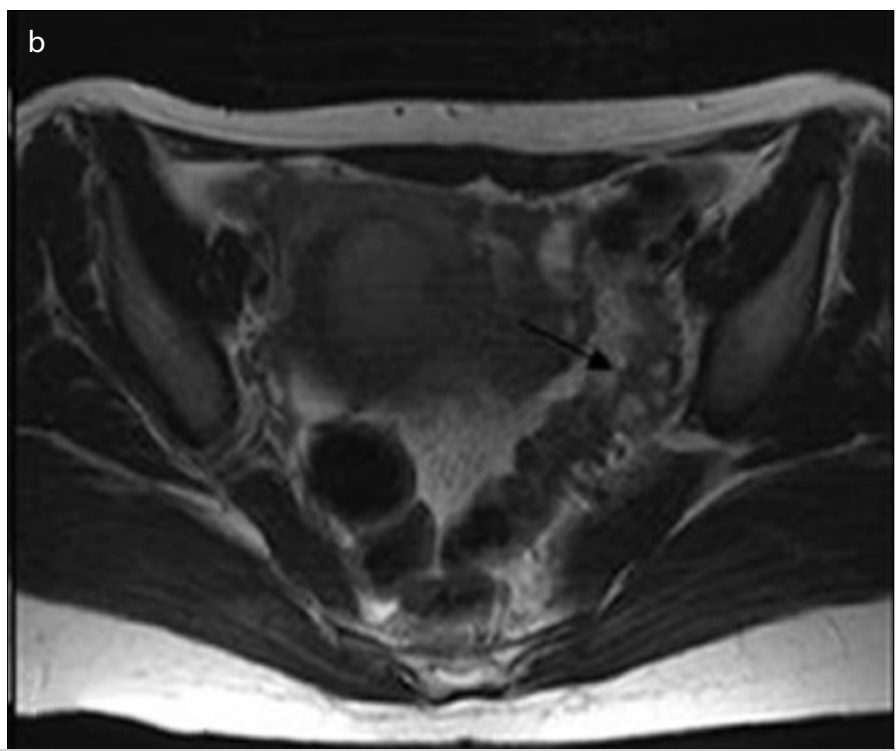

Figure 2. Transverse T2-weighted images shows normal right (a) and left (b) ovaries 


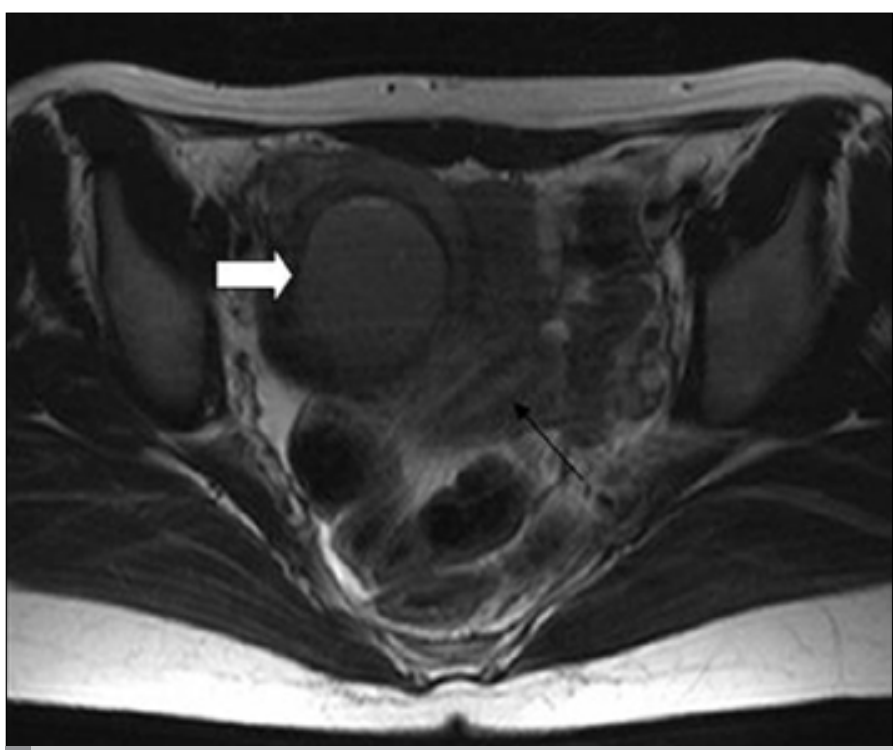

Figure 3. Transverse T2-weighted image shows degenerated myoma (white arrow) in the rudimentary uterine horn and uterine cavity (black arrow)

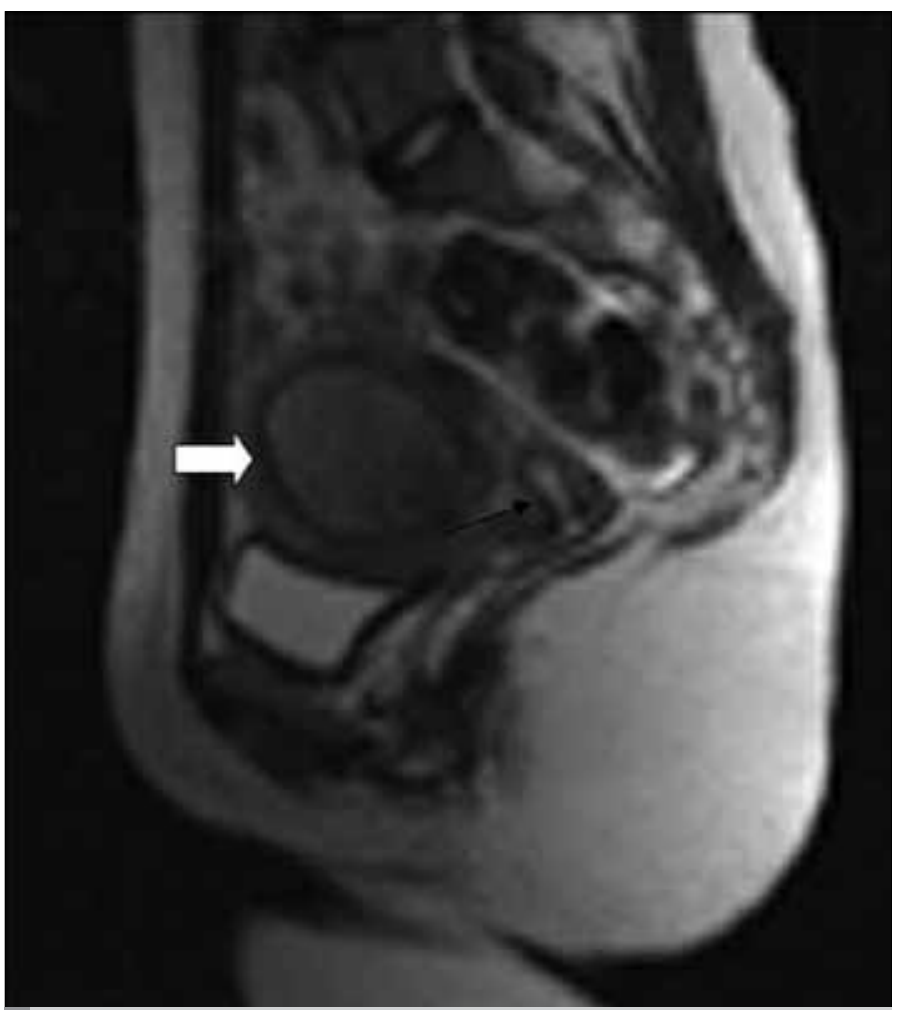

Figure 4. Sagittal T2-weighted image shows degenerated myoma (white arrow) in the rudimentary uterine horn and uterine cavity (black arrow)

sound in evaluating the congenital abnormalities of the uterus. Also, in the literature, uterine anomalies with renal anomalies, obstructed hemivagina, and leiomyoma on the septum of a septate uterus were reported together $(9,10)$. The association of a degenerated myoma and unicornuate uterus with a rudimentary uterine horn has not been reported.
Informed consent: Written informed consent was obtained from patient who participated in this case. Peer review: Externally peerreviewed.

Author contributions: Concept - U.K.; Design - A.N.; Supervision U.K.; Materials - A.N.; Data Collection and/or Processing - A.N.; Analysis and/or Interpretation - M.C.; Literature Review - A.N.; Writer - A.N.; Critical Review - U.K.

Conflict of interest: The authors confirm that there are no conflicts of interest associated with this manuscript.

Financial Disclosure: The authors declared that this study has received no financial support.

Hasta Onamı: Bu olguya katılan hastadan yazılı hasta onamı alınmıştır.

\section{Hakem değerlendirmesi: Dış bağımsız.}

Yazar Katkıları: Fikir - U.K.; Tasarım - A.N.; Denetleme - U.K.; Malzemeler - A.N.; Veri toplanması ve/veya işlemesi - A.N.; Analiz ve/veya yorum - M.C.; Literatür taraması - A.N.; Yazıyı yazan - A.N.; Eleştirel İnceleme - U.K.

Çıkar Çatışması: Yazarlar herhangi bir çıkar çatışması bildirmemişlerdir.

Finansal Destek: Yazarlar bu çalışma için finansal destek almadıklarını beyan etmişlerdir.

\section{References}

1. Golan A, Langer R, Bukovsky I, Caspi E. Congenital anomalies of the müllerian system. Fertil Steril, 1989; 51: 747-55.

2. Dähnert W. Obstetric and gynaecologic disorders. In: Radiology Review Manual, 3th edn Baltimore: Williams and Wilkins, 1996; 763.

3. Scarsbrook AF, Moore NR. MRI appearances of Müllerian duct abnormalities. Clinical Radiology, 2003; 58: 747-54. [CrossRef]

4. Smolders D, Deckers F, Pouillon M, Vanderheyden T, Vanderheyden J, De Schepper A. Ectopic pregnancy within a rudimentary horn in a case of unicornuate uterus. Eur. Radiol. 2002; 12: 121-4. [CrossRef]

5. Fielding JR. MR imaging of Mullerian anomalies: impact on therapy. Am J Roentgenol 1996; 167: 1491-5. [CrossRef]

6. Brody JM, Koelliker SL, Frishman GN. Unicornuate uterus: imaging appearance, associated anomalies and clinical implications. Am J Roentgenol 1998; 171: 1341-7. [CrossRef]

7. Troiano RN, McCarthy SM. Müllerian Duct Anomalies: Imaging and Clinical Issues. Radiology 2004; 233: 19-34. [CrossRef]

8. Pellerito JS, McCarthy SM, Doyle MB, Glickman MG, DeCherney AH. Diagnosis of uterine anomalies: relative accuracy of MR imaging, endovaginal sonography, and hysterosalpingography. Radiology 1992; 183: 795-800.

9. Mirkovic L, Ljubic A, Mirkovic D. Magnetic resonance imaging in the evaluation of uterus didelphys with obstructed hemivagina and renal agenesis: a case report. Arch Gynecol Obstet 2006; 274: 246-7. [CrossRef]

10. Caliskan E, Cakiroglu Y, Turkoz E, Corakci A. Leiomyoma on the septum of a septate uterus with double cervix and vaginal septum: a challenge to manage. Fertil Steril 2008; 89: 456. [CrossRef] 